wiiw Policy Notes and Reports, No. 12

December 2013

\title{
What Remains of the Theory of Demand Management in a Globalising World?
}

Amit Bhaduri

Professor Emeritus, Jawaharlal Nehru University and

Visiting Professor, Council for Social Development, New Delhi, India

Even as societies change, powerful social theories survive, not a coherent body of reasoning but in a 'vulgar' form. The vulgar version is not mere simplification but more like a dogma without foundation in reasoning. And, when this vulgar version enters political discourse, it undergoes yet another mutation. It can be used to justify very opposite policies than was originally intended.

The vulgar version of Keynesian demand management theory to which almost all politicians irrespective of their political colour turn in times of recession is known currently as the 'stimulation doctrine', i.e. stimulating the economy with liquidity from the government and the central bank to save primarily financial institutions. However, it is hoped this will also revive aggregate demand sufficiently to save not only banks but also the real economy suffering from unemployment and excess capacity. This Keynesian policy is pursued however without any appreciation of the fundamental foundations of the theory even in the academia. Indeed most mainstream academic economists, even those who believe themselves to be 'Keynesians', continue to theorise in their technical works in a neo-classical mode. It is characterised by assumptions like representative maximising agent(s), long-run equilibrium positions from which the problem of effective demand has been banished as a 'short-term' problem, and perfect flexibility of prices and wages with substitution between capital and labour induced by relative prices to reflect relative scarcity, the central mechanism for equilibrating the economy at full employment. The only deviations allowed in this neo-classical scheme are short-term failures of the price mechanism due to incomplete information.

And yet, the core of the theories of Kalecki and Keynes (despite some differences especially in dealing with money and income distribution) is derived from an altogether different set of propositions. The essential propositions are:

(1) The analogy between the individual (household) and the economy does not hold due to the circular flow between expenditure and income in the macro-economy where in a double entry national accounting format my expenditure becomes your 
income. As a result, expenditure injected in the circular flow (as autonomous investment) can generate a matching amount of saving by raising income through the multiplier. In this framework higher saving is the consequence of higher investment, and the maximising principle of the individual agent deciding between present and future consumption (saving) is, to say the least, an inessential detail.

(2) In situations of recession the generation of additional income in response to higher expenditure is mostly brought about through an increase in production, as quantities rather than prices respond more vigorously at higher speed even in the short run to higher demand caused by higher autonomous expenditure.

(3) This inverts both the Marshallian and Walrasian presumption that prices rather than quantities adjust in the short run.

(4) In this scheme prices respond to money wages and the level of output responds to the level of demand (expenditure) to permit an approximate separation between determination of prices and quantities. More importantly, the real wage rate becomes an endogenous outcome of the interaction between the price level and the money wage rate which makes the real wage rate an unsuitable policy instrument. Since wage bargain is in money terms only the money wage rate can be changed with indeterminate effect on the extent of change in the price level and the real wage rate.

The theory of demand management was set deliberately in the context of a closed economy without foreign trade to avoid unnecessary debates and detours about the unfortunate experiences of 'beggar-thy-neighbour' policies of competitive devaluation of inter-war years as they amounted to efforts at exporting unemployment. The focus instead was on national policies directed towards domestic markets. ${ }^{1}$ The context of the theory has changed drastically with globalisation.

Old trade rivalries have not disappeared in this new setting but have reappeared in different guises as national economies lost direct control to varying degrees over their exchange rates in a flexible exchange rate regime dominated by private traders. In single currency areas (such as the European Union) no space is left for competitive devaluation, and trade rivalry takes the form of competitive unit cost reduction through national policies for real wage restraint and enhancing labour productivity, the former reducing the size of the domestic market and the latter producing more output at the cost of employment. As a result, the profit margin and share tend to increase weakening consumption demand at home, and the net effect is for a desperate zero sum game pushing simultaneously all countries of the single currency area towards export-led growth inside or outside the area to make a return to the 'beggar-thy-neighbour' policies in a different guise. Losers in this

Based on recollections of two separate conversations with Josef Steindl, a colleague of Kalecki's in Oxford, and with Joan Robinson, a colleague of Keynes' in Cambridge. 
game accumulate debt, government debt and commercial debts for individual firms and households which are taken over ultimately as national debt, while facing austerity measures in a situation of worsening employment at home through shrinking domestic markets on account of a falling wage share and import surplus. The success of the winners on the other hand manifests itself in accumulating assets, mostly as governmentguaranteed liabilities of debtor member countries in the single currency area.

Globally the situation is similar in many ways. The perspective of shifting emphasis from the foreign to the domestic market proposed originally in the theories of demand management is reversed everywhere. Trade rivalry takes the form of targeting competitive unit cost reduction (implying lower inflation to improve the real exchange rate) at the cost of employment generation at home. A particular national currency (US dollar instead of the British sterling) still plays to a large extent the role of international 'money' as a medium of exchange (e.g. in oil and major international insurance contracts) as well as a store of value. This bestows on the concerned debtor country issuing the 'international money' the privilege to finance its trade deficit and other payments like investments (in real estate, natural resource acquisition etc.) by letting debt instruments to accumulate abroad denominated in its own currency. Export surplus countries hold voluntarily these debts as international money. It remains a matter of speculation how long this international exchange of paper liability for real goods and services would remain a viable arrangement. However, academic discussions usually miss the point. Unlike in the case of Britain's attempt to resurrect (1926) and subsequently abandon in humiliation the Gold Standard (1931) in face of an onslaught of downloading of sterling for gold by the rival economic powers, France and the United States, the current situation is somewhat different. Apart from providing an important export outlet, the defence dependence of the important trade surplus countries (such as Japan, Germany, Saudi Arabia) on the United States as the military super power virtually ruled out such aggressive financial diplomacy. And yet, the emergence of China as a massive trade surplus country with independent military power has introduced an unknown variable in the system. While China too depends substantially on the US export market, the possible use of a massive dollar surplus to challenge the hegemony of the dollar remains an open question.

Globalisation has brought about a shift in emphasis with the external market gaining steadily in relative importance over the internal market. This means not only greater openness to trade in goods and services, and in direct foreign investment, but also openness to trade in financial assets. Countries are more tightly linked through a denser network of trade in goods and services driven to a significant extent by multinational firms. It is also the same engine which drives foreign investment in the creation of new physical assets. However, far more important has been the globalisation of finance by multinational banks and other financial institutions through creating an ever increasing volume of debt contracts as derivative claims and insurances on the same set of 'underlying' physical 
assets for trade in foreign exchange denominated assets. Indeed, because of its sheer quantitative importance, this demarcates a new period of financial globalisation in which trade in financial assets completely overwhelms in quantitative significance all other trade in goods, services and foreign direct investments in physical assets. ${ }^{2}$ They are assets traded as titles and entitlements in the secondary (spot and futures) market, arising from different layers of claims of indirect or partial ownership, insurances and guarantees derived from existing 'underlying' assets. These derived claims can be created and multiplied as debt contracts almost at will by the specialised institutions of big finance with high financial standing. The centre of gravity in international finance shifts gradually as 'shadow banking' trading heavily in private debt instruments develops in a thinly supervised financial sector which escapes on the one hand supervision of the monetary authority but foregoes on the other any formal guarantee provided by the 'lender of last resort'. It creates instead its own extensive network of mutual private debt contracts, guarantees and insurances. In 'normal' times, the trust in large, private financial institutions is high and the debt contracts circulate as privately guaranteed 'credit money'. However, somewhat like in an explosive chemical reaction, they act not merely as catalysts speeding up the reaction but produce even more catalysts to accelerate the process. In a closed self-referential system, massive amounts of private debt contracts as credit money become available on demand for fuelling demand for financial assets which are merely other forms of private debt contracts differently packaged for financial investments. This system works well and is pre-disposed towards asset price inflation to keep expectations of capital gains alive.

The asset portfolio of a country undergoes changes in composition due to expectations of changes in exchange rate, monetary (e.g. interest rate) and fiscal policy (e.g. corporate tax rate) of the national governments, affecting expectations of capital gains and losses on asset prices. Since assets are denominated in different currencies and held by nationals of different countries, portfolio changes entail cross-border and cross-currency transactions with the result that expectations of capital gains and losses impact significantly the composition of existing portfolios of assets. This is a two-way process: while national economic policies affect expectations of capital gains and losses, they in turn affect exchange national policies through the channel of international capital flows.

The fear of capital outflow that may be induced by the fiscal policy of the government sets a serious constraint on traditional demand management policies. Unless the sentiments of the financial market is respected sufficiently to keep 'high finance' happy, capital flight becomes a threat to a stable economic environment. Kalecki had foreseen this possibility

According to BIS statistics, the volume of trade in the foreign exchange markets increased from a daily 60 billion in 1983 (when all the capital accounts of OECD countries had been deregulated) to 1490 billion in 1998, and the ratio of foreign exchange transaction to world export rose from world export 12:1 to 100:1 during the same period. The central banks together had a reserve of 1550 billion in 1997, hardly sufficient to cover a single day's trade in the foreign exchange. For more details see D. Nayyar (2006), 'Globalization, history and development', Cambridge Journal of Economics, Vol. 30, pp. 139-157. 
(1943) while discussing the political viability of full employment policies over time and its impact on the 'investment climate' of a country. He had argued that the compulsion of maintaining the authority structure in a capitalist democracy requires the capitalists to retain the initiative of managing the economy by disciplining the workers and having a commanding position in relation to the state. Continuous high employment attained through budget deficit and public spending allows the initiative of policy-making to pass from the captains of industry to the hands of the government. It also weakens the threat of job-loss to workers. The authority structure of a capitalist democracy flourishes instead, if demand management is made to rely on creating a favourable climate for private investment. Therefore pro-active budgetary policies in favour of full employment are resisted and, denying the basic tenet of demand management, it falls back on the false analogy between the individual and the society in the name of 'sound finance' and insistence on the virtues of balanced budget. Given his historical context, Kalecki emphasised the climate for long-term industrial investment. In contemporary circumstances it would be more relevant to talk of the climate for financial investment which is highly mobile and typically short term. This makes the constraint of capital flight even more acute as national economic policies have even less manoeuvrability, and have to keep the financial sector happy almost on a day-to-day basis.

In the context of an open economy the circular flow between total expenditure and income in national accounts implies the identity that an excess of private, corporate or government expenditure (investment) over its income (saving) has to be balanced by a corresponding current account deficit if other sectors maintain income expenditure balance. For developing an argument in favour of the private investment climate, the excess of government expenditure over its revenue is singled out without any convincing economic reason as the main causal factor in this identity for causing a current account deficit on the assumption that other sectors are in balance. ${ }^{3}$ Since a consistent current account deficit can set off a downward spiral of expectations of capital losses on financial assets leading to further capital flight far beyond the initial current account or government budget deficit, it threatens a national currency with the spectre of uncontrollable depreciation.

In the changed circumstances of globalised finance with massive capital flows, the theory of demand management appears to lose its policy relevance. But appearance is not always reality. Demand management policies returned disguised in an unrecognisable vulgar form, compatible with the economic 'austerity measures' in the name of 'sound finance' which restricts government spending and helps to establish the authority structure of finance-dominated capitalism. An acid test of the validity of a social theory, Joan Robinson had perceptively observed, can be judged only when it is separated from its ideological rhetoric. A theory passes this test, when a person changes political side (say)

J. Steindl (1990), 'The control of the economy', chapter 16 (pp. 216-228) in Economic Papers, 1941-88, Macmillan, London. 
from the Left to the Right, but continues to make use of the same theory. ${ }^{4}$ Recent experiences would suggest that the theory of demand management passes this test.

Financial globalisation and the possibility of interest-induced movements of international capital flows increased the importance of monetary policy. With that came a change in the direction of policy of separating monetary from fiscal policy institutionally through the independence of the central bank and targeting inflation rather than employment. Multinational firms with subsidiaries in many countries weakened steadily the ability of governments to collect taxes, as footloose corporations showed their profit in the countries with lower tax rates through 'creative transfer pricing', sub-contracting and threatening to move to more hospitable climates for investment. A competitive reduction in corporate tax rates (followed by later attempts at tax harmonisation) under a regime of relatively mobile capital in relation to less mobile labour steadily increased the ratio of tax on wages and salaries to corporate profit. The uneven sharing of the tax burden fuelled tax payers' dissatisfaction with high taxes which got directed towards inefficiency of public spending by the welfare state with considerable help from corporate-controlled media. Against this background, rolling back the state sector through greater tax cut for the rich became a politically more acceptable strategy even in former social democracies.

However, such redistribution policies in favour of the rich are flawed from the point of view of sustaining aggregate demand in so far as the rich have a higher propensity to save. Rising asset prices provided a way of reconciling Keynesian demand management with fiscal policy induced inequality. Enhancing the emerging authority structure of financial rather than industrial capital the market for financial assets (including housing and real estate as important variables 'underlying' many assets) and the benefit of tax cut was extended further to the rich who own a disproportionately greater proportion of such assets. Cheap money and deregulation helped in sustaining high prices for financial assets as private debt contracts. Buoyant expectations about asset price rises raised simultaneously borrowers' credit worthiness and improved lenders' balance sheets. Indeed, with expectations of continuing capital gains, borrowers could service their growing debt from capital gains while lenders could increase both the volume and margin of lending. A debt-driven consumption boom seemed to resolve the nagging problem of effective demand while consolidating the supreme position of authority of the financial sector in the economy. The old Keynesian model of cooperative capitalism in which the state helped to sustain a sufficient level of demand to maintain both high employment for workers and high profit for industrial capitalists from a high volume of sales gave way to the model of 'Great Moderation' which celebrated the supremacy of the financial sector. Capital inflow attracted by the lure of high capital gains added to the celebration by hiding problems of chronic trade deficits due to high private consumption by borrowing.

4 J. Robinson (1962), Economic Philosophy, chapter 1, London. 
The financial sector can present a show of prosperity increasingly delinked from the working of the real economy so long as prices of financial assets continue to rise. And, sustaining expectations about rising asset prices through increased borrowing for consumption becomes the central mechanism on which this model hinges. Unlike public investment through deficit financing by the state which is meant to lift the economy out of a depressed state of private expectations about profits, this model of 'great moderation' is subject to the fragility of high expectations about private profit from asset price rise. So long as the real economy expands with asset price rise, private debt might be expected to rise faster than public debt sustained by various new debt instruments. They may even be multiplied by various derived private debt contracts of mutual guarantees from the shadow banking sector without either central supervision or a lender of last resort. In this process, the distinction between 'money' guaranteed by the monetary authority and various private credit contracts and insured privately issued by the financial sector becomes increasingly blurred. They are created endogenously by the profit-seeking private financial sector to exploit as well as create new demand for financial assets. This expansion of private credit without restraint fuels further asset price rise. It raises the lure of exceptional returns especially from esoteric assets while a self-referential private credit rating system as a creature of the financial system itself gains importance and underplays risks to keep the show going. And, private credit rating agencies become the guardian legitimising the system, rating not only private credit but sovereign risk meant to rate fiscal policies of a government in terms of its impact on financial markets.

As this process continues the financial system tends to delink itself increasingly from the performance of the real economy in terms of employment and output. The turning point may come in a manner similar to that of the Ponzi game, but on a macroeconomic scale. It is reached when even higher returns have to be promised on financial investment to keep asset prices rising which also changes the composition continuously from real to financial investment. However, financial investment encouraging further financial investment for acquisition of claims (and derived counter claims) on existing assets does not help the real economy in raising demand for goods and services but raises the price of assets. In a more extreme case the real economy may stagnate or even decline while the prices of financial assets and the stock market continue to rise delinked for a while from the state of the real economy. This is the prelude to a financial crisis as the divergence grows between the real and the financial sector of the economy. The probability of default in the real sector increases with stagnant income but rising debt and high asset price. At this point of the Ponzi game, even small event of default can suddenly push the fragile financial sector to a crisis. Defaulted loan has to be covered by liquidity guaranteed by the central monetary authority as lender of last resort (money) and private unguaranteed credit is no substitute, but the elaborate network of expanded private credit contracts is incapable of providing it. Every player in the financial sector now wishes to have their loan secured with adequate 
liquidity, but liquidity is in short supply as everyone had expanded credit contracts through private guarantees. A financial catastrophe due to sudden freeze of credit looms large.

The irony of the situation is that such a collapse of the private financial system can be avoided only by injecting liquidity into the banks by the central monetary authority and government. Largely deregulated private banking and its private system of credit creation has to be rescued by a government which otherwise has been restraining its own budget by reducing social benefits to the poor. This is the prescription offered by both captains of industry and finance for improving the climate for private investment, but they now need the government to deficit finance their rescue package!

However, even this might not be the final irony and the end game of resorting to Keynesian-style demand management, while being in constant denial about its efficacy. Flooding banks and the financial sector with injected liquidity is of limited use when the private investment climate remains depressed in the aftermath of a financial crisis. In a stagnating economy there are not many willing to undertake long-term investment in real assets. The financial sector is salvaged with liquidity but the real economy continues to stagnate with high unemployment and excess capacity. In an economy in the grip of a long recession, under the compulsions of democracy the ultimate irony may turn out to be the old remedy of massive public investment with deficit financing to restore confidence in the climate for private investment! 